\title{
Pengembangan Video Animasi Berbasis Kearifan Lokal pada Pembelajaran IPA Kelas V di Sekolah Dasar
}

\author{
Aprizal Lukman \\ Program Pascasarjana S3 Pendidikan MIPA Universitas Jambi \\ Jl. Raden Mattaher No. 21 Kecamatan Pasar Kota Jambi 36123 \\ Email: aprizallukman@ymail.com \\ Dwi Kurnia Hayati \\ Program Studi Pendidikan Guru Sekolah Dasar FKIP Universitas Jambi \\ Jl. Jambi-Muara Bulian Km 15 Mendalo Indah, Muaro Jambi 36361 \\ Email:dwikurnia_h@unja.ac.id \\ Nasrul Hakim \\ Tadris Biologi IAIN Metro \\ Jl. Ki Hajar Dewantara 15A Iring Mulyo Kota Metro, Lampung \\ Email:nasrulhakim@metrouniv.ac.id
}

Received: September 7, $2019 \quad$ Revised: September 26, $2019 \quad$ Accepted: October 20, 2019

\begin{abstract}
This study aims to develop a video animation of science learning materials on water recycling and natural events. The development model used is the DDD-E model. The product developed was validated by the material validator and the media validator, two and three times, respectively. Then the product is revised according to the suggestions and validator input. The final validation results indicate the product is worth testing with an average score of 4.6 which is included in the highly valid criteria. After that, an animated video product is tested on elementary school students to find out the practicality of the media.
\end{abstract}

Keyword: animation video, science, local wisdom

\begin{abstract}
Abstrak
Penelitian ini bertujuan untuk mengembangkan video animasi pembelajaran IPA materi daur air dan peristiwa alam. Model pengembangan yang digunakan adalah model DDD-E. Produk yang dikembangkan divalidasi oleh validator materi dan validator media, sebanyak masing-masing dua dan tiga kali. Kemudian produk direvisi sesuai saran dan masukan validator. Hasil validasi akhir menunjukkan produk layak diuji coba dengan skor rata-rata 4,6 yang termasuk ke dalam kriteria sangat valid. Setelah itu, produk berupa video animasi diujicobakan kepada peserta didik sekolah dasar untuk mengetahui kepraktisan media.

Kata kunci: video animasi, IPA, kearifan lokal
\end{abstract}




\section{Pendahuluan}

Kajian Ilmu Pengetahuan Alam (IPA) sangat erat kaitannya dengan dunia nyata dan banyak ditemui di lingkungan sekitar seperti tumbuhan, hewan, udara, energi, air, peristiwa alam, dan lain-lain. IPA membahas tentang gejala-gejala alam yang disusun secara sistematik yang didasarkan pada hasil percobaan dan pengamatan yang dilakukan oleh manusia ${ }^{1}$. Pembelajaran IPA di sekolah dasar meliputi materi pengetahuan alam yang sering dijumpai dalam kehidupan peserta didik, sehingga pembelajaran IPA yang bermakna adalah pembelajaran yang dikaitkan dengan kehidupan sehari-hari.

Salah satu materi dalam pembelajaran IPA yang tidak bisa dilepaskan dari kehidupan manusia adalah materi daur air dan peristiwa alam. Daur air disebabkan oleh sifat air yang terus-menerus mengalir dari suatu tempat ketempat yang lain². Dalam siklus tersebut, air mengalami perubahan bentuk dari cair ke uap, kemudian kembali lagi menjadi cair.

Materi daur air yang ditampilkan dalam video pembelajaran yang dikembangkan dalam penelitian ini berlatar sungai Batanghari yang ada di Jambi, dan materi peristiwa alam yang ditampilkan adalah peristiwa alam yang pernah terjadi di Jambi, seperti banjir, tanah longsor, kebakaran hutan, serta peristiwa alam yang sering terjadi di Indonesia yaitu gempa bumi. Dengan demikian, proses pembelajaran menjadi bermakna karena peserta didik merasakan sesuai dengan kondisi nyata di sekitarnya. Daur air dan peristiwa alam tersebut tidak dapat dilihat secara langsung oleh peserta didik, karena

\footnotetext{
${ }^{1}$ Samatowa, U. 2006. Bagaimana Membelajarkan IPA di Sekolah Dasar. Jakarta: Direktorat Pendidikan Nasional, h. 2.

${ }^{2}$ Azam, M. 2009. Akrab dengan Dunia IPA 5 untuk Kelas VSD dan MI. Solo: PT Tiga Serangkai Pustaka Mandiri, h. 156.
}

tidak semua peristiwa alam dapat dilihat proses terjadinya. Beberapa peristiwa alam berlangsung dengan cepat, serta ada pula peristiwa alam yang dapat membahayakan jika dilihat secara langsung. Dalam kondisi ini, media pembelajaran berperan penting.

Media adalah suatu perantara yang dapat menyalurkan informasi dari sumber informasi kepada pihak yang memerlukan informasi ${ }^{3}$. Media pembelajaran merupakan bagian yang tidak dapat dipisahkan dari proses pembelajaran. Menggunakan media dalam pembelajaran, membuat peserta didik lebih tertarik dalam mengikuti pembelajaran dan memberikan pengaruh yang baik pada pemahaman terhadap materi ${ }^{4}$. Manfaat lain dari media yaitu dapat menyederhanakan pesan, mengurangi verbalistis, menyamakan persepsi, menarik perhatian, serta dapat menghemat waktu 5 .

Media pembelajaran yang baik untuk digunakan di sekolah dasar adalah yang sesuai dengan karakteristik siswa sekolah dasar seperti: masih senang bermain, senang bergerak, suka meniru, senang merasakan dan melakukan sesuatu secara langsung, serta senang bekerja dalam kelompok. Perkembangan kognitif yang terjadi antara usia 7 dan 11 tahun disebut oleh Piaget sebagai tahap operasional konkret (cocrete operations stage) ${ }^{6}$. Peserta didik pada tahap oprasional konkret telah mampu berpikir logis, namun hanya untuk hal-hal yang konkrit. Pemilihan kelas V pada penelitian ini dengan alasan perkembangan kognitif

${ }^{3}$ Asyar, R. Khairinal. 2010. Media Pembelajaran Sekolah Dasar. Jakarta: Gaung Persada (GP) Press Jakarta.

${ }^{4}$ Rozie, F. 2013. Pengembangan Media Video Pembelajaran Daur Air untuk Meningkatkan Proses dan Hasil Belajar IPA Siswa Kelas V SD Negeri Bintoro 02 Jember.Jurnal Pendidikan Sains Universitas Negeri Malang Vol 3 No.2

${ }^{5}$ Wati, E R. 2016. Ragam Media Pembelajaran. Yogyakarta: Kata Pena, h. 2.

${ }^{6}$ Danim, S. 2014. Perkembangan Peserta Didik. Bandung: Alfabeta, h. 64. 
peserta didik kelas $\mathrm{V}$ sedang berada pada fase tersebut. Peserta didik lebih tertarik pada objek konkrit, sehingga peserta didik mampu menggunakan mentalnya untuk memecahkan masalah yang bersifat konkrit.

Berbagai karakteristik peserta
didik tersebut, mengkondisikan guru
untuk menyediakan media pembelajaran yang sesuai agar pembelajaran menjadi menyenangkan, salah satunya dengan video animasi. Media video tergolong dalam media audio visual yang dapat menampilkan unsur gambar dan suara secara bersamaan pada saat mengkomunikasikan pesan atau informasi ${ }^{7}$. Dengan menggunakan, video peserta didik dapat dengan mudah memahami isi materi karena memfungsikan dua indera sekaligus yaitu telinga dan penglihatan. Selain itu video disajikan dengan bentuk animasi yang sesuai dengan dunia anak, sehingga dalam penyajiannya peserta didik seolah sedang menonton film animasi tetapi pesan yang disampaikan mengandung obyek-obyek yang sedang dipelajari.

\section{Metode}

Model pengembangan yang menjadi acuan pada penelitian ini yaitu model DDD-E, di mana model DDD-E didesain khusus untuk digunakan dalam pengembangan multimedia pembelajaran. Model DDD-E terdiri dari: 1) Decide atau menetapkan tujuan dan materi program, 2) Design atau desain yaitu membuat struktur program, 3) Develop atau mengembangkan adalah memproduksi elemen media dan membuat tampilan, 4) Evaluate atau mengevaluasi yaitu mengecek seluruh proses desain dan pengembangan ${ }^{8}$.

Tahap decide meliputi kegiatan menetapkan tujuan pembelajaran,

${ }^{7}$ Wati, E R. 2016. Ragam Media Pembelajaran. Yogyakarta: Kata Pena, h. 5.

${ }^{8}$ Tegeh, M, Jampel, N, Pudjawan, K. 2014. Model Penelitian Pengembangan. Yogyakarta: Graha Ilmu. menentukan tema danruang lingkup multimedia, mengembangkan kemampuan prasyarat, serta menilai sumber daya. Tahap design merupakan tahap berpikir visual karena menghasilkan keseluruhan produk dalam bentuk outline konten, flowchart, dan storyboard.Kemudian pada tahap develop, produk dikembangkan dalam bentuk video animasi yang disusun beberapa elemen di dalamnya seperti gambar, tulisan, animasi, dan audio. Setelah memilih semua elemen tersebut, lalu dilakukan proses editing video dengan menggunakan Sofware Adobe After Effects CS6. Setelah video selesai dikembangkan maka dilakukan validasi dan uji coba produk. Setiap tahapan yang dilakukan pada penelitian pengembangan dievaluasi untuk memperbaiki kualitas produk yang dikembangkan

Instrumen yang digunakan dalam penelitian ini berupa angket berpedoman skala likert dengan skala 5. Menurut Riduwan,skala likert digunakan untuk mengukur sikap, pendapat, dan persepsi seseorang atau sekelompok tentang kejadian atau gejala sosial ${ }^{9}$. Angket digunakan untuk validasi, mengukur kepraktisan, dan kemenarikan produk.

\section{Hasil dan Pembahasan}

Hasil dari penelitian dan pengembangan ini berupa video animasi berbasis kearifan lokal pada pelajaran IPA kelas V di sekolah dasar. Video animasi kemudian divalidasi untuk mengetahui kelayakan produk dan diuji coba untuk menguji kepraktisannya. Tampilan awal produk yang akan divalidasi dapat dilihat pada tabel 1 .

${ }^{9}$ Riduwan. 2013. Skala Pengukuran VariabelVariabel Penelitian. Bandung: Alfabeta, h. 12. 
Tabel 1 Tampilan awal produk

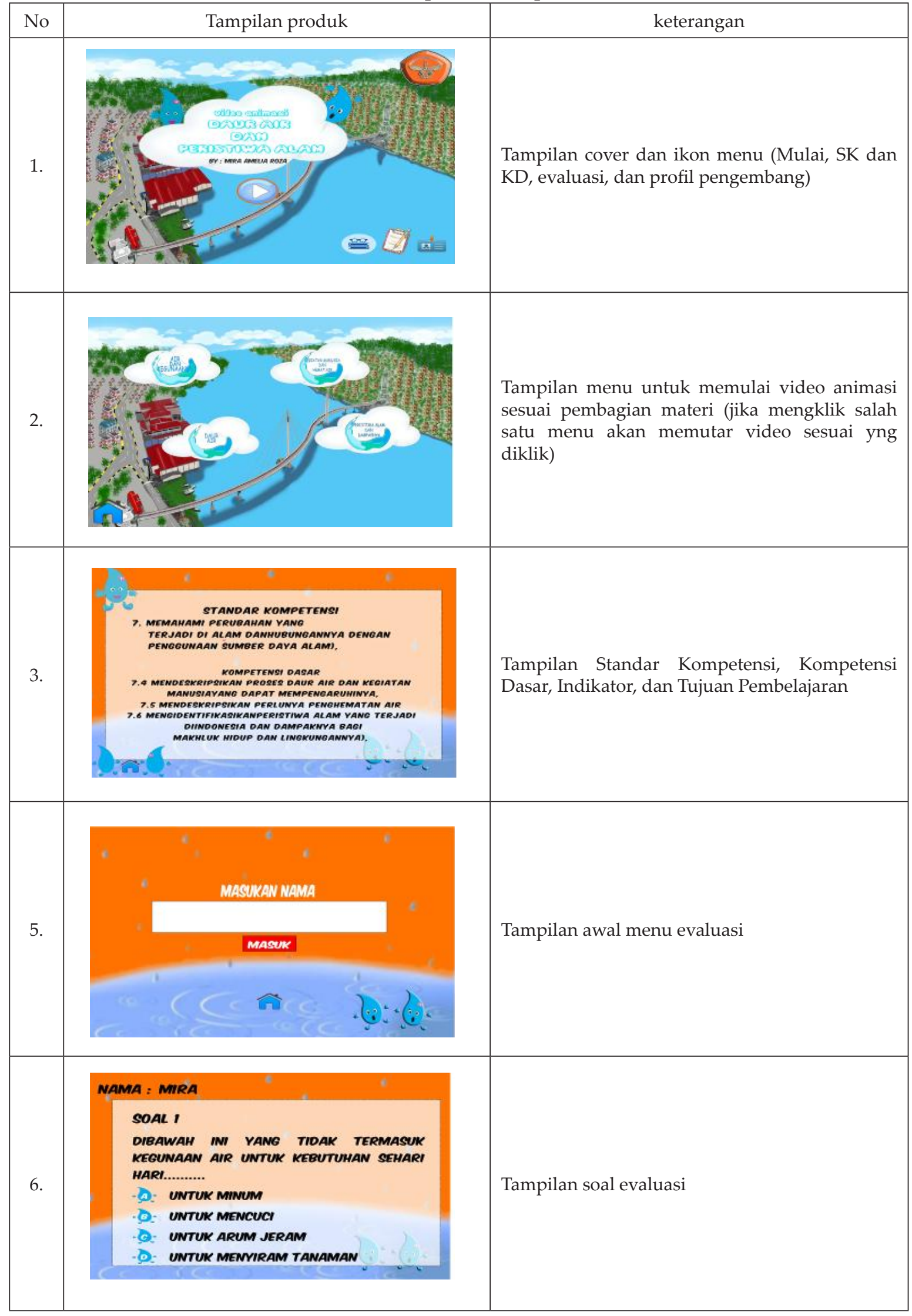




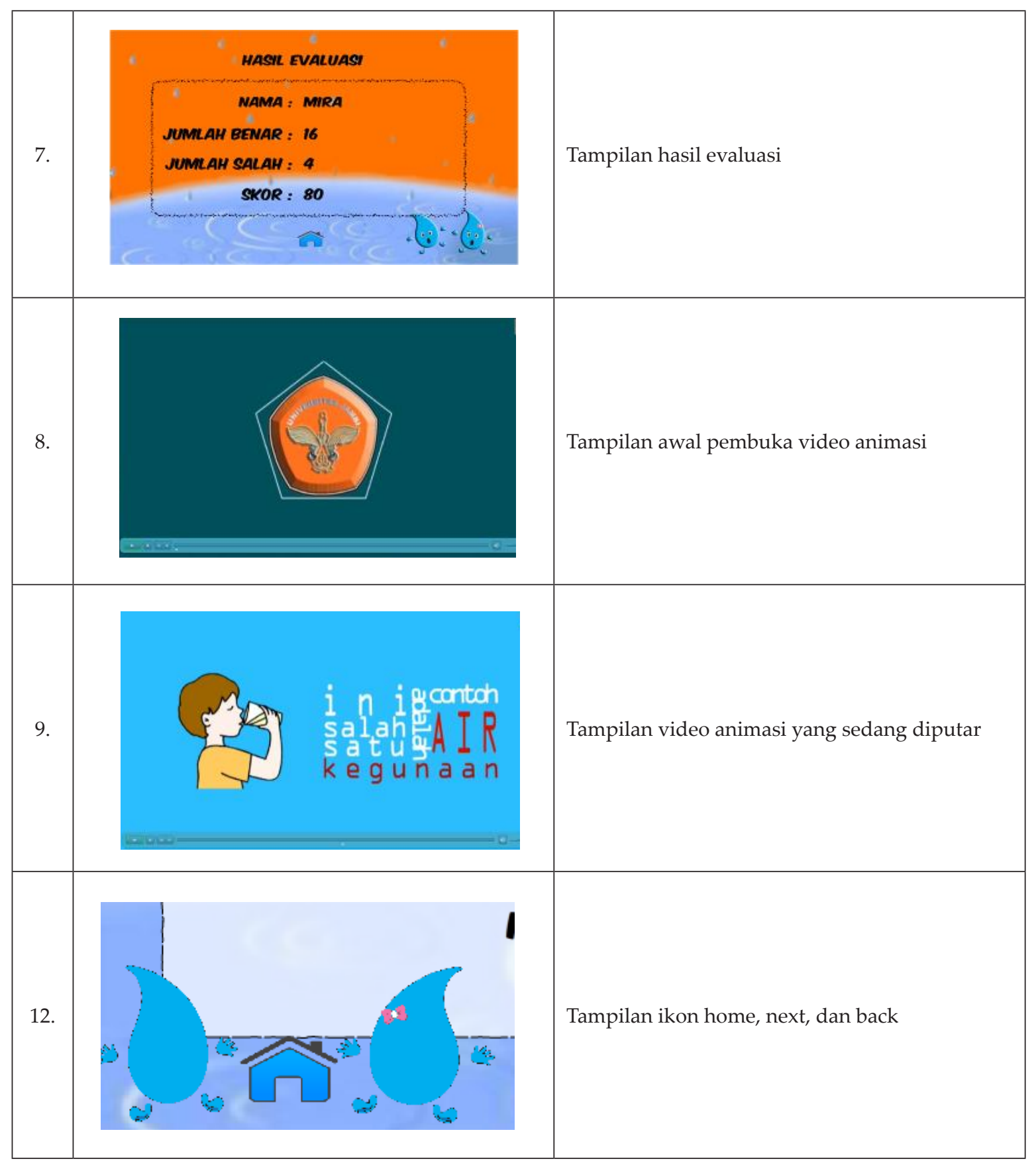

\section{Validasi}

Validasi yang dilakukan terdiri dari validasi media dan validasi materi. Hasil validasi media, bagian-bagian yang harus diperbaiki antara lain 1) pada menu untuk memulai video yang pada tampilan awalnya dijabarkan satu-persatu sehingga tidak diketahui materi mana yang seharusnya terlebih dahulu dipelajari, sebaiknya berikan pemisahan pada menu tersebut agar sesuai dengan kompetensi mana yang 
didahulukan untuk pemahaman peserta didik, 2) gambar yang ditampilkan untuk mengenal kebakaran hutan tidak begitu jelas sebaiknya menggunakan gambar asli/nyata sesuai dengan lingkungan peserta didik supaya bisa terlihat jelas, 3) animasi yang diberikan pada tulisan jangan berlebihan sebaiknya menggunakan animasi yang sesuai sehingga dapat terbaca, 4) warna tulisan pada profil pengembang tidak sesuai dengan backgroundnya sehingga tulisan tidak terlihat jelas, sebaiknya warna tulisandganti, 5)Musik pengiring diganti dengan instrumen guruku tersayang, sesuai karakter peserta didik SD. Kemudian peneliti merevisi produk sesuai dengan saran yang diberikan oleh validator dan sesuai dengan literatur yang diperoleh. Perbaikan tersebut dapat dilihat pada tabel 2.

Tabel 2 Tampilan produk sebelum revisi dan sesudah revisi oleh validator media

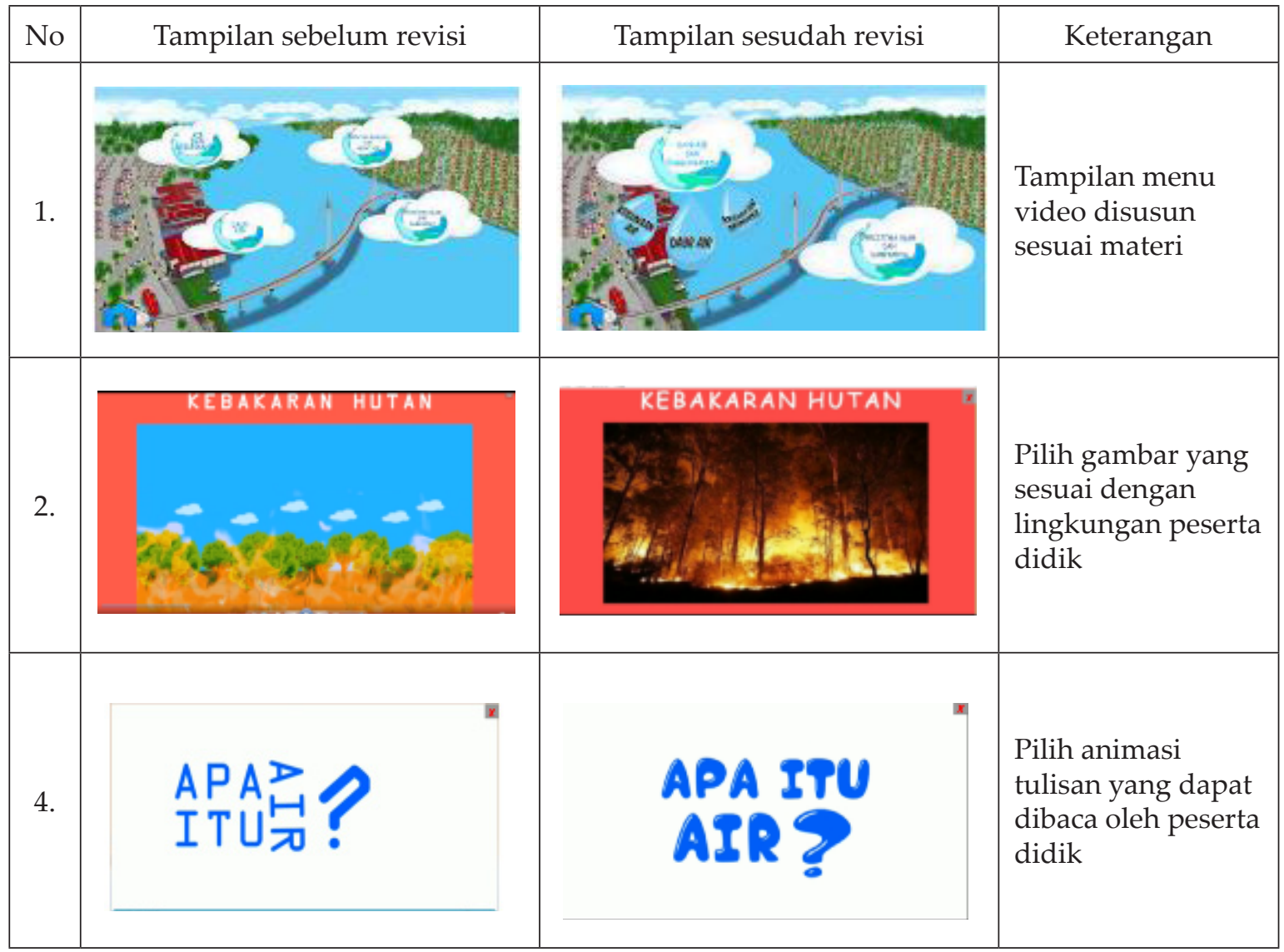

Setelah perbaikan selesai, produk video animasi kembali divalidasi. Hasil validasi kedua menyatakan bahwa produk valid tanpa perbaikan, atinya produk sudah layak untuk diujicoba. Penilaian yang diberikan oleh validator media dapat dilihat pada tabel 3. 
Tabel 3 Hasil penilaian validator media

\begin{tabular}{|c|l|c|c|}
\hline \multirow{2}{*}{ No } & \multicolumn{1}{|c|}{ Butir penilaian } & \multicolumn{2}{c|}{$\begin{array}{c}\text { Skor penilaian } \\
\text { (validasi ke 1 dan 2) }\end{array}$} \\
\cline { 3 - 4 } & & 1 & 2 \\
\hline 1. & Kesesuaian tampilan dengan background & 3 & 4 \\
\hline 2. & Kombinasi warna yang menarik & 1 & 4 \\
\hline 3. & Kesesuaian musik pengiring dengan narasi & 2 & 3 \\
\hline 4. & Suara yang disajikan jelas & 4 & 5 \\
\hline 5. & Antara suara dengan animasi sesuai & 2 & 4 \\
\hline 6. & Kesesuain setting gambar dan animasi & 4 & 5 \\
\hline 7. & Kesesuaian penyajian gambar dengan materi yang dibahas & 3 & 4 \\
\hline 8. & Animasi tulisan yang ditampilkan jelas dan menarik & 1 & 4 \\
\hline 9. & $\begin{array}{l}\text { Ilustrasi mudah dipahami dan sesuai dengan kehidupan } \\
\text { sehari-hari }\end{array}$ & 2 & 4 \\
\hline 10. & Kualitas video bagus & 4 & 4 \\
\hline 11. & Isi video runtut sesuai materi & 29 & 45 \\
\hline \multicolumn{2}{|c|}{ Jumlah } & 2,6 & 4,1 \\
\hline
\end{tabular}

Berdasarkan tabel 3 pada validasi ke-1 diperoleh jumlah nilai rata-rata yaitu 2,6 dimana pada point 3 dan 9 hanya mendapat skor "1" yaitu "sangat tidak setuju", dan pada point 4,6, dan 10 hanya mendapat point " 2 " yaitu "kurang setuju". Menurut keterangan dari validator hal itu dikarenakan pada point ke-3 musik pengiring pada video animasi terlalu kencang diawal pemutaran dan tidak bertema ke SD-an, pada point ke-9 ilustrasi tidak mudah dipahami peserta didik karena bentuk tulisan yang disajikan tidak mudah dibaca, pada point ke-4 suara musik lebih keras pada suara narasi sehingga suara narasi tidak terdengar, pada point ke-6 pada salah satu video pergerakan video terlalu cepat, dan pada point ke-10 kualitas video yang disajikan masih pecah-pecah dan goyang. Berdasarkan saran yang diberikan oleh validator tersebut maka dilakukan perbaikan produk yang selanjutnya divalidasi kembali dan memperoleh hasil rata-rata 4,1.

Validasi materi kemudian dilakukan untuk melihat kevalidan materi pada video animasi berbasis kearifan lokal ini. Validasi dilakukan sebanyak tiga kali. Hasil penilaian validator dapat dilihat pada tabel 4 .

Tabel 4 Hasil penilaian validator materi

\begin{tabular}{|c|l|c|c|c|}
\hline & \multicolumn{1}{|c|}{ Butir penilaian } & \multicolumn{3}{|c|}{$\begin{array}{c}\text { Skor penilaian } \\
\text { (validasi ke 1,2, } \\
\text { dan 3) }\end{array}$} \\
\cline { 3 - 5 } & \multicolumn{1}{|c|}{$\begin{array}{c}\text { Ko } \\
\text { pelengkapan materi yang disajikan sesuai dengan kehidupan sehari-hari }\end{array}$} & 3 & 4 & 5 \\
\hline 2. & $\begin{array}{l}\text { Kedalaman materi yang disajikan sesuai jabaran yang mendukung } \\
\text { pencapaian Kompetensi Dasar (KD) }\end{array}$ & 2 & 4 & 5 \\
\hline
\end{tabular}




\begin{tabular}{|c|l|c|c|c|}
\hline 3. & $\begin{array}{l}\text { Keakuratan runtutan penyampaian materi dalam video animasi sesuai } \\
\text { pembelajaran IPA }\end{array}$ & 2 & 3 & 4 \\
\hline 4. & Keakuratan prosedur yang disajikan sesuai pembelajaran IPA & 2 & 4 & 4 \\
\hline 5. & Keakuratan ilustrasi dan contoh sesuai dengan lingkungan peserta didik & 2 & 3 & 4 \\
\hline 6. & Kesesuaian video animasi dengan tingkat perkembangan peserta didik & 2 & 4 & 5 \\
\hline 7. & Kesesuaian materi dengan perkembangan jaman & 4 & 4 & 5 \\
\hline 8. & Keruntutan dan keterpaduan alur pikir dalam video animasi & 2 & 3 & 4 \\
\hline 9. & Mendorong untuk mencari informasi lebih jauh & 4 & 4 & 5 \\
\hline 10. & Kemenarikan materi yang disajikan menggunakan video animasi & 4 & 4 & 5 \\
\hline 11. & Kesesuaian dengan tingkat perkembangan intelektual peserta didik & 2 & 4 & 5 \\
\hline 12. & Kesesuaian dengan tingkat perkembangan sosial emosional & 4 & 4 & 5 \\
\hline 13. & Ketersampaian materi dengan baik melalui video animasi & 2 & 3 & 4 \\
\hline \multicolumn{2}{r}{ jumlah } & 35 & 48 & 60 \\
\hline & 2,6 & 3,6 & 4,6 \\
\hline
\end{tabular}

Berdasarkan tabel 4 pada validasi ke-1 skor yang diperoleh yaitu 2,6 yaitu "cukup valid". Pada point 2, 3, 4, 5, 6, 8, 11 , dan 13 hanya memperoleh skor " 2 ". Hal ini dikarenakan pada point ke-2 masih ada indikator yang belum dijabarkan dalam kompetensi dasar, pada point ke-3 materi dampak dari peristiwa alam belum dimasukkan, pada point ke-4 materi pada peristiwa alam belum runtut, pada poin ke-5 pelangi yang disajikan dlam video kurang jelas pemisahan warnanya, pada point ke-6 penyampaian materi pada video ketiga terlalu cepat sehingga tidak sesuai dengan tingkat kognitif peserta didik, pada point ke-8 gambar orang minum yang disajikan terpotong sehingga peserta didik tidak tahu orang minum tersebut sedang duduk atau berdiri, sebaiknya cari gambar orang yang sedang minum sambil duduk, pada point ke-11 sesuaikan dengan perkembangan intelektual peserta didik. Dan pada point ke-13 tambahkan lagi materi-materi yang tertinggal dan sesuaikan video animasi dengan perkembangan peserta didik. Media dikatakan "belum layak dan masih membutuhkan revisi".
Pada validasi ke-2 media telah diperbaiki mengikuti komentar dan saran dari validator. Skor yang diperoleh yaitu 3,6 "valid" dengan membutuhkan "perbaikan" pada point ke 3,5,8, dan 13 hanya memperoleh skor " 3 ". Untuk point pertama masih ada materi yang tata letaknya tidak simetris, pada point ke-2 karakter yang digunakan dalam air memberi kesan pemisahan gender sehingga diberi saran untuk menyeseuaikan karakteristik peserta didik, pada point ke-3 alur pikir dalam video masih belum runtut untuk materi dampak kebakaran, dan pada poin ke-13 materi belum bisa dikatakan tersampaikan dengan baik karena alurnya belum runtut. Menurut Arsyad, keterpaduan mengacu pada hubungan yang terdapat diantara elemen visual yang ketika diamati akan berfungsi bersama-sama sebagai satu keseluruhan sehingga visual merupakan bentuk yang menyeluruh membantu pemahaman pesan dan informasi yang dikandungnya ${ }^{10}$. Hasil validasi ke-2 ini media sudah dikatakan "layak" tapi masih membutuhkan revisi.

${ }^{10}$ Arsyad, A. 2011.Media Pembelajaran.Jakarta: Raja Grafindo Persada, h. 108. 
Setelah media direvisi kemudian divalidasi kembali.Skor yang diperoleh dari hasil validasi ke-3 yaitu 4,6 dengan keterangan media "sangat valid" dan "layak diuji cobakan tanpa revisi". Tampilan akhir media setelah melalui tahap validasi disajikan pada tabel 5 .

\section{Uji Coba}

Produk yang telah divalidasi selanjutnya diujicobakan pada subjek uji coba kelompok kecil yaitu peserta didik kelas VA SDN 34/I Teratai berjumlah 6 orang dengan kemampuan yang berbeda-beda. Uji coba ini dilakukan untuk memperoleh data kepraktisan produk yang dikembangkan.

Tabel 5 Tampilan akhir produk

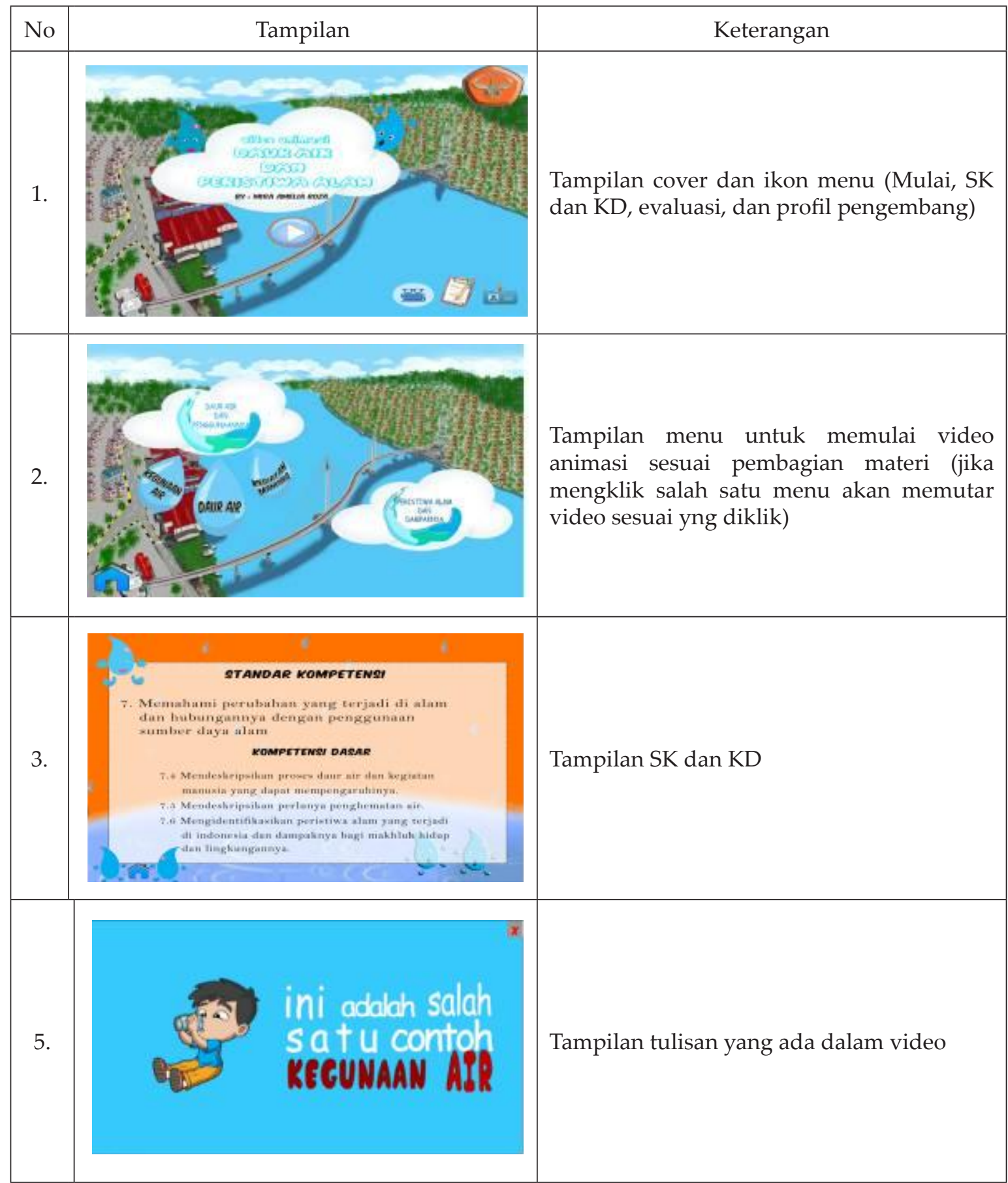




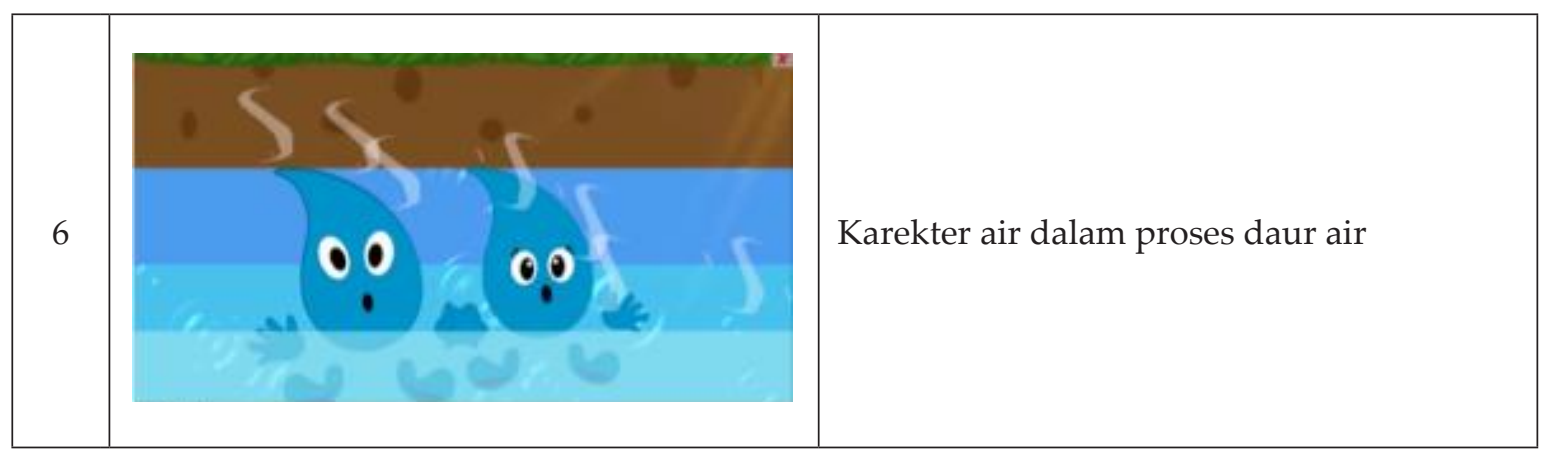

Pertimbangan kepraktisan dapat dilihat dalam aspek kemudahan penggunaan, dapat digunakan sewaktu-waktu, waktu singkat, cepat, sebagai pengganti atau variasi serta biaya murah jika hendak menggunakannya ${ }^{11}$.Peserta didik diminta mengamati peneliti dalam menggunakan media dengan bantuan laptop, dan LCD proyektor, peneliti menjelaskan tentang penggunaan produk tersebut sesuai dengan menu-menu yang terdapat pada video animasi. Penyajian media, peserta didik diminta mengamati setiap materi yang diuraikan dalam video animasi untuk materi daur air dan peristiwa alam. Setelah penyampain materi peserta didik maju satu-persatu untuk menyelesaikan evaluasi yang bersifat interaktif dalam media tersebut, sehingga peserta didik dapat mengetahui pengetahuan yang didapat setelah menggunakan video animasi dengan terteranya nilai pada layar.

Setelah uji coba dilakukan, peneliti melakukan pemberian angket pada 6 orang peserta didik yang telah mengamati penggunaan video animasi tersebut. Adapun hasil yang diperoleh dari angket tersebut dapat dilihat pada tabel 5.

Berdasarkan sepuluh kategori pernyataan yang tertera pada angket yang diberikan kepada 6 peserta didik, kesimpulan yang diperoleh yaitu media yang digunakan menarik dan peserta didik merasa senang ketika menggunakan video animasi tersebut. Materi yang dijabarkan dengan ilustrasi gambar sesuai dengan kehidupan sehari-hari peserta didik dan juga peserta didik menjadi tertantang dalam mengerjakan soal evaluasi.

Pengisian angket kepraktisan dilakukan oleh guru kelas V. Guru kelas tersebut mengamati materi yang disajikan, melihat SK dan KD, serta soal evaluasi yang ada dalam video animasi. Kemudian peneliti memberikan angket respon guru terhadap produk video animasi dan hasilnya terdapat pada tabel 6 .

Guru meberikan komentar atau saran secara umum terhadap media pembelajaran video animasi yang dikembangkan yaitu video animasi yang dikembangkan sangat menarik dari bentuk produknya dan dalam penyajiannya, materi yang terdapat dalam video animasi telah sesuai dengan kurikulum dan mengandung unsur-unsur edukasi. Gambar-gambar yang ditampilkan membuat peserta didik merespon positif sehingga peserta didik terlihat antusias dalam mengamati dan melakukan tes evaluasi.

${ }^{11}$ Rifai, H. 2011. Praktikalitas Modul Berbasis Masalah pada Perkuliahan Kalkulus I di STKIP PGRI Sumatera Barat.Jurnal Stkip PGRI Padang Vol 2 No.1 Tahun 2012, h. 3. 
Tabel 5Hasil penilaian respon peserta didik

\begin{tabular}{|c|c|c|c|c|c|c|c|c|c|}
\hline \multirow{2}{*}{ No. } & \multirow{2}{*}{ pernyataan } & \multicolumn{6}{|c|}{ Jumlah Peserta Didik } & \multirow{2}{*}{ Jumlah } & \multirow{2}{*}{$\begin{array}{l}\text { Rata- } \\
\text { rata }\end{array}$} \\
\hline & & P1 & P2 & P3 & $\mathrm{P} 4$ & P5 & P6 & & \\
\hline 1. & $\begin{array}{l}\text { Video animasi yang disajikan } \\
\text { membuat saya tertarik dalam } \\
\text { mengikuti pelajaran }\end{array}$ & 5 & 5 & 5 & 5 & 5 & 5 & 30 & 5 \\
\hline 2. & $\begin{array}{l}\text { Video animasi menyajikan } \\
\text { gambar dan suara yang jelas dan } \\
\text { mudah saya pahami }\end{array}$ & 4 & 5 & 5 & 4 & 5 & 4 & 27 & 4,5 \\
\hline 3. & $\begin{array}{l}\text { Ilustrasi materi yang disajikan } \\
\text { video animasi memudahkan saya } \\
\text { dalam memahami materi daur air } \\
\text { dan peristiwa alam }\end{array}$ & 5 & 5 & 5 & 5 & 5 & 5 & 30 & 5 \\
\hline 4. & $\begin{array}{l}\text { Kombinasi tulisan, gambar, dan } \\
\text { suara yang disajikan dalam video } \\
\text { animasi sudah baik }\end{array}$ & 3 & 5 & 5 & 3 & 5 & 5 & 26 & 4,3 \\
\hline 5. & $\begin{array}{l}\text { Ilustrasi materi yang disajikan } \\
\text { dekat dengan kehidupan sehari- } \\
\text { hari }\end{array}$ & 5 & 5 & 5 & 5 & 4 & 5 & 29 & 4,8 \\
\hline 6. & $\begin{array}{l}\text { Video animasi membuat suasana } \\
\text { belajar jadi tidak membosankan }\end{array}$ & 3 & 5 & 5 & 4 & 5 & 5 & 27 & 4,5 \\
\hline 7. & $\begin{array}{l}\text { Menu dalam video animasi } \\
\text { mudah untuk saya gunakan }\end{array}$ & 3 & 5 & 5 & 4 & 5 & 4 & 26 & 4,3 \\
\hline 8. & $\begin{array}{l}\text { Video animasi ini membuat saya } \\
\text { semangat dan antusias dalam } \\
\text { mengikuti pelajaran IPA materi } \\
\text { daur air dan peristiwa alam }\end{array}$ & 4 & 5 & 5 & 5 & 5 & 5 & 29 & 4,8 \\
\hline 9. & $\begin{array}{l}\text { Video animasi membuat saya } \\
\text { antusias dan tertantang untuk } \\
\text { mengerjakan soal-soal evaluasi } \\
\text { materi daur air dan peristiwa } \\
\text { alam }\end{array}$ & 4 & 5 & 5 & 5 & 4 & 4 & 27 & 4,5 \\
\hline 10. & $\begin{array}{l}\text { Secara keseluruhan saya tertarik } \\
\text { video animasi pada materi daur } \\
\text { air dan peristiwa alam }\end{array}$ & 5 & 5 & 5 & 4 & 5 & 5 & 29 & 4,8 \\
\hline \multicolumn{9}{|c|}{ Jumlah } & 46,5 \\
\hline \multicolumn{9}{|c|}{ Rata-rata } & 4,65 \\
\hline & Kategori & Sang & $\mathrm{tme}$ & & & & & & \\
\hline
\end{tabular}

Tabel 6 Hasil penilaian respon guru

\begin{tabular}{|c|l|c|}
\hline No. & \multicolumn{1}{|c|}{ Peryataan } & Skor \\
\hline 1. & $\begin{array}{l}\text { Penyajian materi dalam video animasi sudah mencakup semua kompetensi } \\
\text { dasar }\end{array}$ & 5 \\
\hline 2. & Materi yang disampaikan sesuai dengan tujuan pembelajaran yang akan dicapai & 5 \\
\hline 3. & $\begin{array}{l}\text { Kejelasan materi yang disajikan dalam video animasi pada materi daur air dan } \\
\text { peristiwa alam sudah jelas dan mudah dipahami peserta didik }\end{array}$ & 4 \\
\hline 4. & $\begin{array}{l}\text { Penampilan gambar, tulisan, dan suara dalam video animasi dapat mendorong } \\
\text { minat belajar peserta didik }\end{array}$ & 5 \\
\hline
\end{tabular}




\begin{tabular}{|c|l|c|}
\hline 5. & Video animasi praktis dalam penyajiannya & 4 \\
\hline 6. & Menu dalam video animasi mudah untuk digunakan & 4 \\
\hline 7. & Alat bantu dalam penyajian telah tersedia di sekolah (infokus) & 5 \\
\hline 8. & Video animasi bisa digunakan sebagai media belajar mandiri bagi peserta didik & 4 \\
\hline 9. & Video animasi dapat memotivasi peserta didik dalam belajar & 5 \\
\hline 10. & $\begin{array}{l}\text { Evaluasi yang disajikan dalam video sesuai dengan materi daur air dan peristiwa } \\
\text { alam }\end{array}$ & 5 \\
\hline \multicolumn{2}{|c|}{ Jumlah } & 46 \\
\hline \multicolumn{2}{|c|}{ Rata-rata } & $\begin{array}{c}\text { Sangat } \\
\text { praktis }\end{array}$ \\
\hline
\end{tabular}

\section{Evaluasi}

Pada tahap evaluasi pengembang melihat sejauh mana keberhasilan produk video animasi dalam proses pembelajaran, sesuai dengan harapan awal atau tidak. Evaluasi dapat dilakukan di setiap tahap pengembangan dimulai dari kevalidan media yang dilakukan oleh validator sampai dinyatakan layak oleh validator. Evaluasi juga dilakukan setelah mengetahui tanggapan responden terhadap penggunaan media pembelajaran yang telah dilakukan. Evaluasi ini merupakan evaluasi formatif, karena tujuannya hanya untuk kebutuhan revisi. Setelah tahap develop (pengembangan) dilakukan uji coba produk, penulis memperoleh data berupa hasil angket. Dari data angket tanggapan responden sebagian besar responden di SDN 34/I Teratai menyukai produk yang dikembangkan pada materi daur air dan peristiwa alam dengan memberikan respon yang positif. Kesesuaian video animasi dalam pembelajaran serta kemenarikan dan kepraktisan dari video animasi yang disajikan mampu membuat siswa tertarik dalam mempelajari materi pembelajaran dan membantu siswa lebih mudah dalam memahami materi daur air dan peristiwa alam.

\section{Kesimpulan}

Berdasarkan hasil penelitian dan pengembangan video animasi berbasis kearifan lokal pada pelajaran IPA kelas V di sekolah dasar ini dapat disimpulkan.

1. Pengembangan video animasi berbasis kearifan lokal pada pelajaran IPA kelas V di sekolah dasar ini menggunakan model pengembangan DDD-E dangan empat tahapan pengembangan yaitu: decide, design, develop, dan evaluate.

2. Pengembangan video animasi berbasis kearifan lokal pada pelajaran IPA kelas $\mathrm{V}$ di sekolah dasar dinyatakan sangat valid dengan tingkat kevalidan 4,1 pada validasi media dantingkat kevalidan 4,6 pada validasi materi.

3. Pengembangan video animasi berbasis kearifan lokal pada pelajaran IPA kelas $\mathrm{V}$ di sekolah dasar dinyatakan sangat menarik dan praktis, dengan tingkat kemenarikan 4,65 serta tingkat kepraktisan 4,6.

\section{Saran}

Saran yang dapat peneliti sampaikan yaitu agar dapat dilakukan penelitian selanjutnya mengenai efektifitas produk yang sudah dikembangkan dalam penelitian ini. Selain itu, penelitian dan pengembangan 
media animasi dengan menggunakan sofware adobe colection CS6untukmateri pembelajaran IPA yang lainsehingga dihasilkan produk yang lebih menarik yang dapat mempermudah peserta didik dalam memahami materi.

\section{Daftar Pustaka}

Arsyad, A. 2011.Media Pembelajaran.Jakarta: Raja Grafindo Persada.

Asyar, R. Khairinal. 2010. Media Pembelajaran Sekolah Dasar. Jakarta: Gaung Persada (GP) Press Jakarta.

Azam, M. 2009. Akrab dengan Dunia IPA 5 untuk Kelas VSD dan MI. Solo: PT Tiga Serangkai Pustaka Mandiri.

Danim, S. 2014. Perkembangan Peserta Didik. Bandung: Alfabeta

Riduwan. 2013. Skala Pengukuran VariabelVariabel Penelitian. Bandung: Alfabeta.

Rifai, H. 2011. Praktikalitas Modul Berbasis Masalah pada Perkuliahan Kalkulus I di Stkip PGRI Sumatera Barat.Jurnal STKIP PGRI Padang Vol 2 No.1 Tahun 2012

Rozie, F. 2013. Pengembangan Media Video Pembelajaran Daur Air untuk Meningkatkan Proses dan Hasil Belajar IPA Siswa Kelas V SD Negeri Bintoro 02 Jember.Jurnal Pendidikan Sains Universitas Negeri Malang Vol 3 No.2 Tahun 2013

Samatowa, U. 2006. Bagaimana Membelajarkan IPA di Sekolah Dasar. Jakarta: Direktorat Pendidikan Nasional.

Tegeh, M, Jampel, N, Pudjawan, K. 2014. Model Penelitian Pengembangan. Yogyakarta: Graha Ilmu.

Wati, E R. 2016. Ragam Media Pembelajaran. Yogyakarta: Kata Pena. 
166| Hlementitiry Vol. 5 No. 2, July -December 2019

This page intentionally left blank 